\title{
Environmental and Public Health Impact of Poorsolid Waste Disposal in Kano Metropolis Nigeria
}

\author{
Article by Kabiru Mustapha Y \\ Texila American University School of Public Health Guyana South America \& Economics \\ Department Bayero University Kano Nigeria \\ E-mail: kmyakasai2003@yahoo.com
}

\begin{abstract}
Poor solid waste disposal is one of the major environmental and public health issues in Kano Metropolis, like in other cities in Nigeria and developing world at large. Poor solid wastes disposal pose threat to public health and environmental quality in the metropolis. The objective of this study was to examine the environmental and public health impact of poor solid waste disposal in Kano metropolis.

The study was cross sectional descriptive studies, simple random sampling technique was applied to sample the study population, and structured questionnaire were designed, pretested and re-distributed to participants. Secondary data sources were used. The result revealed that overall there were 554 households participated, with a response rate of 539 (98\%). Demographic characteristics of respondents indicated 236 (44\%) males, 303females (56\%), marital status of the respondent indicated 198 (37\%), were marriage, and other demographic characteristics. The result shows significant findings that relates to poor solid wastes disposal and the impact on environment and public health, $75 \%$ of household engaged in open mass dumping of solid wastes, other factors that contributes to poor solid waste disposal were observed and documents, distance to disposal sites, household storage of wastes, and poor separation of wastes. Over 77\% households had perception about disease transmission from poor solid waste disposal. 53\% had good knowledge about diseases related to solid waste disposal. Significant awareness as well as perception was good among the households but there is poor behavior in terms of effective management of solid waste, proper health education message dissemination must be enforced for better behavioral change by the relevant authorities.
\end{abstract}

Keywords: Environment, Health Solid waste Disposal, Dumpsite.

\section{Introduction}

Poor solid waste disposal is one of the major environmental problems in Kano Metropolis like other cities in Nigerian States. Developing countries are facing the same issues. Solid waste management problems in Kano are as a result of so many factors such as urbanization due to rapid population growth, commercial activities, agricultural and industrial are among the factors. Government in adequate commitments, such as poor funding, in adequate equipments for transport and disposal, poor communities awareness and participation, poor town planning, in adequate involvement of private sectors are among other factors affecting the solid waste management system. (Muktar, 2011). Improper solid waste management contaminate the environment, causes all types of pollution, contamination of water sources etc., according to United State Public Health Service identifies 22 human diseases that are linked to improper management of municipal solid wastes (Pervez, 2013).

Muhammad, (2016) and Loretta, et al (2017) highlighted that poor Solid waste disposal have impact on the environment and public health and can results in causing environmental pollution and spreads of diseases. A significant proportion of the diseases burden in African countries is determinant of environmental factors (Adegbite, 2016). Twenty five percent of diseases are attributable to the environment due to poor solid waste management. There are linkages with many environmental determinants and as a result of human activities that could lead to outbreak of environmental related 
diseases like malaria, diarrhea, cholera, typhoid, skin and eye infections as well as upper respiratory diseases from open burning of the garbage (Abu Salam (2007, Angela et'al, 2014, and Beatrice, (2013).

In Kano metropolis presently, illegal disposal sites continue to increase at an alarming rate; these will definitely possess danger to the environment, and public health. Few studies were conducted to find out the impact of poor disposal of wastes in Kano with regards to contamination of underground water (Ahmed, 2017). Study findings revels traced of some environmental contaminants in areas surrounding disposal sites. Government failure to address the issue of illegal disposal of solid wastes is one key factor that continues to affect the solid waste disposal policy in the State. However, current practice of disposal of solid wastes in the State through the use of sanitary land filling in the metropolis is done though open dumping as a crude method of land filling whereby no proper separation of biodegradable wastes from non-biodegradable as well. For effective and sustained solid waste management operations government must adopt strategies to ensure safe disposal of solid wastes in the state, these strategies must include both legal measures and policy implementation, because if care is not taken this will possess danger to the environment and public health generally (Aliyu, 2010 and Modebe et'al, 2009)

Indiscriminate disposal of solid wastes can presents direct or indirect effects on the environment and the public health generally. The effects of improper solid wastes disposal activities are widely recognized issue as cited by many related studies such as (Christensen et'al, 2001, 2003, Bacco, and Agunwamba, 2003). The environmental and public health impact of poor solid waste disposal is not fully understood according to Medina, (2003), Wilson et'al, (2006) and Pate (2012). Many health impact of poor solid wastes disposal depends on the type of exposure, nature of the waste, disposal site proximity etc. Common environmental impact includes contamination of underground water quality, emission of odor, breeding places of insects, such as flies, mosquitoes and dumping rodents.

Moreover, health impact includes the following transmission of infections such as cholera, typhoid fever, gastro enteritis, dysentery, soil transmitted helminthes infections, and Lassa fever on rare cases (Pate, 2012). Waste management of municipal solid waste in Nigeria has suffered neglect from the government at all levels and still facing many challenges in which, environmental agencies and the general public cannot control it. This will creates an in sanitary situation in many parts of the cities; this can leads to exposure to environmental hazards related to exposure due poorly managed solid wastes. Common environmental and health issues include water contamination, transmission of diseases such as diarrhea, malaria, and blockage of drainages that leads to flooding. Breeding places of insect vectors such as mosquitos and flies (Shridar, 1992, and Aliyu 2015).

According to Muktar, (2008) and Malumfashi et al., (2011) highlighted that poor solid waste disposal practice in Kano metropolis contributes significantly to flooding, breeding of insect and rodent /vectors infestation, transmission and spread of environmental related diseases. Many landfills exists in the metropolis but are poorly managed because standard operation procedures for the disposal are followed in the metropolis. Majority of households in Kano metropolis are practicing open dumping and this makes environmental pollution to be high especially in areas around disposal sites and the underground water pollution can be high. Contaminated underground water as reported by Pate, (2012) from physicochemical analysis of many sampled water collected near disposal sites in Kano metropolis revealed a significant level of contaminants above permissible levels in those areas, the contamination were due to leachate contamination as result of natural and human activities

\section{Objectives}

The following objectives were as follows

1. To examine and assess the household disposal options weather they have impact on health or the environment in the Kano metropolis

2. To identify the factors contributing to poor solid wastes disposal in Kano metropolis.

3. To assess the households perceptions on environmental and public health impact of poor solid waste disposal in Kano metropolis 
4. To assess the awareness on the likely effects of living closer to solid waste dumping sites in Kano metropolis.

5. To proper recommendations based on findings.

\section{Methods}

The study was designed to assess the environmental and public health impact of poor solid waste disposal in Kano Metropolis. The study was cross sectional descriptive study using survey methods, structural questionnaires were designed pre-tested and adopted. The study population comprised of adults (both males and females) of the age of 18years and above in the study area who are conversant with the concept of waste generation, and disposal. For the inclusion criteria participants were resident of the area, and must be households, willing to voluntarily participate in the study. Nonresidents of the area and those who decide not to participate will be excluded. For the sampling technique in the study, simple random sampling was applied during the studies, it is one of the methods of probability sampling, and a basic type of sampling because according to the principles of simple random sampling is that, every object has the same probability of being selected or chosen. Moreover, simple random sampling is always giving chance to every member of the study area to have an equal probability of being selected to be part of the study. The sampling technique was applied due to the constraints posed by in adequate financial resources and time.

The formula below was applied to compute the sample size for the study.

$\mathrm{n}=\frac{\mathrm{Z}^{2} \mathrm{PQ}}{\mathrm{d}^{2}}$

$\mathrm{n}=$ minimal sample size when population is $>10,000$ )

$\mathrm{z}=$ standard normal deviate at $96 \%$

Confidence interval at 1.96

$\mathrm{p}=$ proportion of households utilizes solid wastes management services from previous study where:-

$\mathrm{p}=0.61 \%$ (from previous study conducted by Obiageli, 2016)

$\mathrm{Q}=1-\mathrm{P}$.i.e. $\mathrm{Q}=0.39$

$\mathrm{d}=$ margin error at $95 \%$ confidence interval

$\mathrm{d}=0.05$

In this descriptive study we felt that the calculated sample size was two small therefore we

Introduced power to increase the sample size

Where: $n=\underline{\left(Z_{\infty}+Z_{\beta}\right)}$

Obiageli, (2016) reported the evaluation of the efficiency of solid waste collection services in Owerri metropolis in Nigeria, reported about $61 \%$ efficiency in waste collection in the study area as conducted by Nwakocha et'al (2011).

$\mathrm{P}=0.61, \mathrm{q}=1-\mathrm{p}=0.39$

$\mathrm{D}=$ degree of accuracy $=0.05$

Power $=0.20$ at $80 \%$

. $(1.96+0.20)^{2}=(2.16)^{2}$

$=\underline{4.6656 \times 0.61 \times 0.39}$

$0.05 \times 0.05$

$=443 / 1-0.20$

$\mathrm{n}=554$.

Data collection during the study followed series of activities such as: desk review, field observation, collection of primary and secondary data from sources in order to present findings on the environmental and public health impact of poor solid wastes disposal in the study area. The structured questionnaires were designed pre-tested and administered; it was made of close- ended and open-ended questions. 
DOI: $10.21522 / \mathrm{TIJPH} .2013 .05 .04 . A r t 007$

ISSN: $2520-3134$

Secondary data sources included books, journals, conference proceedings, newspapers, internet sources and other published documents were accessed.

Data analysis in this study data was done by Statistical Package for Social Sciences (SPSS) version 16 to create dummy variables. The entire dummies was be assigned to numeric values that was computed by the SPSS software. Data cleaning was done in order to check the data file for accuracy and completeness. This was followed by data entry according to the assigned codes. The output result was use to draw conclusions in relation to the research questions.

\section{Result and discussion}

\section{Demographic characteristics of respondents}

Table 1 presents the demographic characteristics of respondents as follows

The result revealed that overall there were 554 who participate with a response rate of 539 (98\%). Table 1 present the demographic characteristics of respondents. There were different age groups, which ranges from 45-54 years (29\%) as the highest age group, this show most of them were household, lowest age were 15-24 year (22\%) who are households at lower age. The sex for the respondents indicated 236 (44\%) were males, $303(56 \%)$ females, this shows how most of the females engaged in handling solid wastes at home than females. The marital status shows $198(37 \%)$ were marriage, $96(18 \%)$ as singles. Education attainment indicated $180(33 \%)$ as secondary which was the highest, the lowest education was $90(17 \%)$ tertiary, this show the reasons why participants have good perception with regards to problems that can generates from poor solid waste disposal due to effects of secondary education, and tertiary education. Those with informal education were 109 (20.2\%). Highest occupation of the respondent was civil servant $158(29.3 \%)$ as highest followed by 51 (9.1) as other occupation, this try to show most of them are urban dwellers. Those with lowest highest income were $210(39 \%)$ and lowest income as 91 (17\%). This is another valid findings indication those who at lower socio-economic status engaged in open dumping compared with those who have highest income as they can afford better solid waste management services than those with lower income, and can be a victim's health impact of poor solid waste disposal.

\section{What are the solid waste disposal options that have impact on health and environment?}

Table 2 presents the findings for solid waste disposal options that have impact on public health and environment, when respondents were asked to specifically indicate their existing household disposal options, they mentioned open dumping 403 (75\%), Land filling 45 (8.\%), Incineration 43 8\%) composting $17(3 \%)$, other disposal options $31(6 \%)$. According to the above table $X^{2=} 1268.9$ and p-value of $<0.0001$ the result is significant with $\mathrm{p}<.05$ we have to concluded that household disposal options have significant impact on environment and public health

The above findings were in consistent with the work of (Muktar, 2011, Aliyu, 2008, Pate, 2012, and Butu, 2009, and Patrick 2015) they discovered that poor solid waste disposal in discriminately in many Nigerian cities such as Kano, Lagos, Abakaliki and Onisha is responsible for many environmental and health problems associated with solid wastes. Sridhar, (1995) reported similar problems related to poor disposal of solid waste in many Nigerian cities, that have negative impact on the environment and health in general. Aliyu (2008b) reported that poor solid waste disposal is responsible for transmission of diseases especially to residents neighboring solid waste dump sites.

\section{What are the factors contributing to poor solid wastes disposal}

The factors that contributes to poor solid waste disposal were presented on table 3 above, from the table it was evidently shows many factors contributing to poor solid waste disposal. The above findings were consistence with the work of Foday, (2013) were he pointed that on the distance to disposal site is one of the factors that affect solid waste collection and disposal, and at the same time have direct or indirect effect to the resident's health living near the solid waste dump site. Where solid waste is kept at 
household $\mathrm{X}^{2}=34.06$, and $\mathrm{p}$-value of $<0.0001$ the result is significant at $\mathrm{p}<.05$, separation for solid waste before disposal $X^{2}=788.6$ and $\mathrm{p}$-value of 0.0001 , the result is significant at $\mathrm{p}<.05$, for disposal at unapproved sites $X^{2}=406.53$ and $p$-value $<0.0001$ the result was also significant at $p<.05$.

\section{Perceptions on environmental and public health impact of poor solid waste disposal}

From table 4 above, the findings were significance and concluded that households have good perception on environmental and health impact of poor solid waste disposal. For perceptions on poor solid waste disposal $X^{2}=652.8$ and p-value. $<0.00001$ the result is significant at $\mathrm{p}=<0.5$. Perception on problems related to poor solid waste disposal $X^{2}=1119.03$, and p-value. $<0.00001$ the result is significant at $\mathrm{p}=<0.5$. For perception of knowledge on poor solid waste disposal and disease transmission $X^{2}=691.64$ and $\mathrm{p}$-value. $<0.00001$ the result is significant at $\mathrm{p}=<0.5$. Perception that pest are related to poor solid waste disposal and has impact health and environment $X^{2}=414.4$ and p-value. $<0.00001$ the result is significant at $\mathrm{p}=<0.5$. Findings of Kaoje, (2017) about resident perceptions of poor solid waste disposal practice in Sokoto metropolis Nigeria highlighted that many residents were disposing solid waste indiscriminately and having poor perceptions of its implications, this can present danger to the environment and the health of the residents. This finding is consistent with Longe (2009) about People's Perception on Household Waste Management in Ojo LGA Lagos Nigeria, according to the findings respondents perceived the effect of poor solid waste disposal at it related to disease transmission like malaria, Lassa fever, and other environmental infections.

\section{Awareness on the likely effects of living closer to solid waste dumping sites}

From the findings on the table 5 above shows that there was good awareness about the impact of living near solid waste disposal site, this is consistent with the findings of Foday (2012) that shows households are not happy with regards to living closer to solid waste disposal site as they complained about sickness, odors, insect vectors as well as rodent breeding places in Granville Brook of Free Town in Sierra Leon, this is as a result of some level of awareness recorded among the study population that is similar among their counter parts living closer to solid waste dump site. Findings from Studies conducted by Pate, (2012) indicated linkages with solid waste disposal sites and contamination of underground water quality, same findings indicated contamination of underground water to all the disposal sites due to leachate activities. According to the studies conducted by Inuwa (2014), revealed that impact of solid waste disposal sites has significant effect on water quality due to natural and human activities. He further concluded that the level of some physical and chemical qualities of water parameters in some sampled hand dug wells were evaluated as the water samples were found to have same levels of phosphates at excess level as the $\mathrm{PH}$ of the water was slightly acidic due to and the traces of phosphates increase the algal bloom. The color, temperature and taste of the analyzed sample water were found to be independent of distance to disposal sites (Pate, 2012 and Inuwa 2014). According to the report of (DEFRA, 2004, L) on environmental impact of solid waste management facilities, it reported significant findings on the impact of solid waste dumpsite at Dandora on environmental pollution and impact on public health because the findings shows traces of high levels of heavy metals and other contaminants. 
DOI: $10.21522 /$ TIJPH.2013.05.04.Art007

ISSN: 2520-3134

Figures and tables

Table 1. Socio demographic characteristics

\begin{tabular}{|c|c|c|}
\hline Variable (Age groups in years) & Frequency & $\%$ \\
\hline $15-24$ years & 116 & 21.5 \\
\hline 25-34 years & 65 & 12.5 \\
\hline $35-44$ years & 148 & 27.5 \\
\hline $45-54$ years & 156 & 28.9 \\
\hline $55 \&$ above & 54 & 10.0 \\
\hline Total & 539 & 100 \\
\hline \multicolumn{3}{|l|}{ Sex of the respondents } \\
\hline & 236 & 44.0 \\
\hline \multirow[t]{2}{*}{ Females } & 303 & 56.0 \\
\hline & 539 & 100 \\
\hline \multicolumn{3}{|l|}{ Marital status } \\
\hline Single & 96 & 17.8 \\
\hline Married & 198 & 36.7 \\
\hline Widowed & 85 & 15.8 \\
\hline Divorced & 160 & 29.7 \\
\hline Total & 539 & 100 \\
\hline \multicolumn{3}{|l|}{ Level of education } \\
\hline Informal & 109 & 20.2 \\
\hline Primary & 160 & 29.7 \\
\hline Secondary & 180 & 33.4 \\
\hline Tertiary & 90 & 16.7 \\
\hline Total & 539 & 100 \\
\hline \multicolumn{3}{|l|}{ Occupation } \\
\hline Farming & 82 & 15.2 \\
\hline Petty trading & 137 & 25.4 \\
\hline Business & 111 & 20.6 \\
\hline Civil servant & 158 & 29.3 \\
\hline Others & 51 & 9.5 \\
\hline Total & 539 & 100 \\
\hline \multicolumn{3}{|l|}{ Income in Naira } \\
\hline $1,000-10,000$ & 95 & 18.0 \\
\hline $10,001-20,000$ & 210 & 39.0 \\
\hline $20,001-30,000$ & 105 & 19.0 \\
\hline $30,00140,000$ & 91 & 17.0 \\
\hline 40,001 \& Above & 38 & 7.0 \\
\hline Total & 539 & 100 \\
\hline
\end{tabular}

(Source: Field work, 2017) 
Table 2. Existing household solid wastes disposal options

\begin{tabular}{|l|l|l|}
\hline Variables & Frequency & Percentage \\
\hline $\begin{array}{l}\text { Solid waste } \\
\text { disposal options } \\
\text { sought }\end{array}$ & & \\
\hline Open dumping & 403 & 74.8 \\
\hline Land filling & 45 & 8.3 \\
\hline Incineration & 43 & 8.0 \\
\hline Composting & 17 & 3.2 \\
\hline Other & 31 & 5.8 \\
\hline
\end{tabular}

Source: Author's field survey (2017)

\section{Solid Wastes Disposal options}

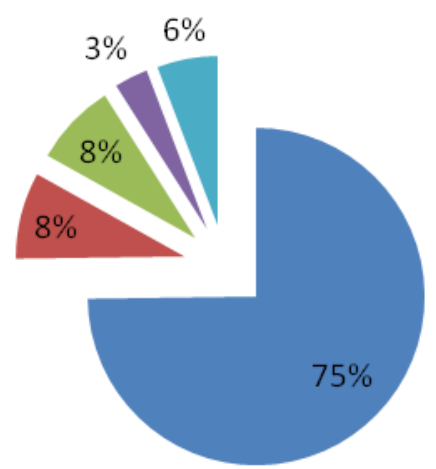

Open dumping

- Land filling

Incineration

Composting

mother

Figure 1. Solid wastes disposal options source (field survey, 2017)

Table 3. Factors contributing to poor solid waste disposal

\begin{tabular}{|l|l|l|}
\hline Variables & Frequency & Percentage \\
\hline Distance to disposal site & & \\
\hline $5-10$ minutes & 352 & 65.3 \\
\hline $11-15$ minutes & 106 & 19.6 \\
\hline $16-20$ minutes & 31 & 5.8 \\
\hline$>20$ & 50 & 9.3 \\
\hline Where solid waste stored before disposal? $(\mathrm{n}=539)$ & & \\
\hline Kept inside the compound & 429 & 79.6 \\
\hline Kept outside the compound & 69 & 12.8 \\
\hline Others & 41 & 7.6 \\
\hline Do you separate waste before disposal? $(\mathrm{n}=539)$ & & \\
\hline Yes & 500 & 92.8 \\
\hline No & 39 & 7.2 \\
\hline Reasons for separation of solid waste & & \\
\hline Maintaining static view & 373 & 69.2 \\
\hline Economic reasons & 64 & 11.9 \\
\hline Good best practice & 34 & 6.3 \\
\hline Volume reduction & 68 & 12.6 \\
\hline Frequency of solid wastes disposal & & \\
\hline & & \\
\hline
\end{tabular}


DOI: $10.21522 / \mathrm{TIJPH} .2013 .05 .04 . A r t 007$

ISSN: $2520-3134$

\begin{tabular}{|l|l|l|}
\hline Daily & 299 & 55.5 \\
\hline Twice a week & 165 & 30.6 \\
\hline Weekly & 58 & 10.8 \\
\hline Monthly & 17 & 3.2 \\
\hline Disposal at un-approve site & & \\
\hline Yes & 435 & 80.7 \\
\hline No & 104 & 19.3 \\
\hline Waste bin utilized by type & & \\
\hline Plastic & 323 & 59.9 \\
\hline Galvanized iron & 158 & 29.4 \\
\hline Local basket & 33 & 6.1 \\
\hline Others & 25 & 4.6 \\
\hline
\end{tabular}

(Source Field work, 2017)

Table 4. Perceptions of households on environmental and public health impact of poor solid waste disposal in the study area

\begin{tabular}{|l|l|l|}
\hline Perception of poor solid waste disposal & Frequency & \% \\
\hline $\begin{array}{l}\text { Poor solid waste disposal is related to disease } \\
\text { transmission }\end{array}$ & & \\
\hline Yes & 519 & 96.3 \\
\hline No & 20 & 3.7 \\
\hline If No why (n=20) & 14 & 70.0 \\
\hline It cannot transmit disease Doesn't know & 6 & 30.0 \\
\hline $\begin{array}{l}\text { Perceptions on problems related to poor solid } \\
\text { waste disposal }\end{array}$ & & \\
\hline Diseases transmission & 417 & \\
\hline Bad/offensive odour & 108 & 77.4 \\
\hline Dirty environment & 13 & 20.0 \\
\hline Air pollution & 1 & 2.4 \\
\hline $\begin{array}{l}\text { Knowledge about diseases related to poor } \\
\text { solid waste disposal }\end{array}$ & & 0.1 \\
\hline Malaria & 286 & \\
\hline Diarrhea & 41 & 53.1 \\
\hline Cholera & 183 & 7.6 \\
\hline Typhoid & 28 & 34.0 \\
\hline Lassa fever & 1 & 5.2 \\
\hline $\begin{array}{l}\text { Poor Solid Waste disposal is responsible for } \\
\text { pest infestations }\end{array}$ & & 0.2 \\
\hline Yes & 518 & \\
\hline No. & 21 & 96.1 \\
\hline $\begin{array}{l}\text { The following pest relates to poor solid } \\
\text { wastes disposal }\end{array}$ & & 3.9 \\
\hline Flies & 104 & \\
\hline Ants & 39 & 19.3 \\
\hline Rodents & 897 \\
\hline Mosquitoes & & 16.5 \\
\hline Soure find & \\
\hline
\end{tabular}

(Source field work, 2017) 
Table 5. Respondent's awareness on the likely effects for living near solid waste dump site

\begin{tabular}{|l|l|l|}
\hline Living near solid waste dump site & Frequency & \% \\
\hline Contaminates environment & & \\
\hline Yes & 303 & 56.2 \\
\hline No & 236 & 43.8 \\
\hline Living near solid waste dump site has impact on health & & \\
\hline Yes & 344 & 63.8 \\
\hline No & 195 & 36.2 \\
\hline $\begin{array}{l}\text { Living near solid waste dump site is related to } \\
\text { nuisances:- }\end{array}$ & & \\
\hline Smells/odors & 222 & 41.2 \\
\hline Smokes & 53 & 9.8 \\
\hline Flies infestations & 16 & 3.0 \\
\hline Rodents & 212 & 39.3 \\
\hline Flooding & 5 & 0.9 \\
\hline Underground water pollution & 21 & 3.9 \\
\hline Others & & \\
\hline Living near solid waste dump site causes illness & & \\
\hline Yes & 501 & 92.9 \\
\hline No & 38 & 7.1 \\
\hline Type of illnesses suffered: & & \\
\hline Malaria & 418 & 77.6 \\
\hline Diarrhea & 46 & 8.5 \\
\hline Typhoid & 54 & 10.0 \\
\hline Asthma & 21 & 3.9 \\
\hline $\begin{array}{l}\text { Diseases associated with dump sites takes long time to } \\
\text { manifest }\end{array}$ & & \\
\hline Yes & 488 & 90.5 \\
\hline No & 51 & 9.5 \\
\hline Source field & \\
\hline
\end{tabular}

(Source field work, 2017)

\section{Conclusion}

From the above findings and discussion there is clear evidence that poor disposal options such as open dumping of solid waste, the associating factors affecting solid waste management contributed to environmental and public health impact of poor solid waste disposal. Moreover, perceptions and awareness of respondents on problems from poor solid waste disposal depends on educational level, in come earnings and occupation, this is in consistent with the findings of (Foday, 2013, Abu Salam, 2007, Angela, Angela et al., 2014, Banjo, 2009). Solid waste management policy were poorly implemented existing policies are not effective, and only few studies are available that have significance finding on impact of poor solid waste disposal and contamination of underground water quality. Researches are limited especially on assessing the exposure risk and health outcomes, this pose poor understanding of the existing impact on public health and the environment. The findings on this paper can be used as an advocacy tool or materials to solicit support from policy makers, environmental and public health professionals for urgent solution to the problems. This is important because the effect is not just to those handling solid wastes or living closer to disposal sites, it is an environmental and health challenges for all the general public and it requires strategic approaches to ensure all waste are managed in such manner that it cannot constitute danger to human health and the environment. 
DOI: $10.21522 / \mathrm{TIJPH} .2013 .05 .04 . A r t 007$

ISSN: $2520-3134$

\section{Recommendations}

There is need by the government and relevant stakeholders to review and strengthen the solid waste management policy to checkmate indiscriminate disposal of solid waste, as it can pose environmental and public health impact with time.

1. Robust Community mobilization on health education messages to community members should be plan and implemented regularly using media sources such as radio television to creates awareness about the impact of poor solid waste disposal; this can drastically change the poor attitude and behavior of the community members towards poor solid waste deposal.

2. The culture of recycling and its benefit to the community should be emphasized, because recycling can help in reducing the volume of waste generated, and reduce the need for exploitation of raw materials.

3. There is need for government to seek partnership collaboration mechanisms to address the problems for waste management through research, community engagement and promoting the use of current technology for safe disposal of solid wastes.

4. Urban development, land and physical planning ministries or departments must stress the need for effective planning and siting of solid waste disposal sites when it comes to town planning of new towns and cities.

5. Regular environmental monitoring by ministries of health and environment for physicochemical analysis of underground water closer to solid waste disposal sites in order to detect evidence of contamination due to leachate activity in order to take prompt action in time.

\section{Acknowledgement}

I am grateful to TAU staff including my study coordinators and faculty members for their effort in correction and guidance to produce this task, I also thanked the organizers for TAU e-conference for their effort to see the 2017 e-conference become a reality through their tireless effort. I thanked the effort of Professor Mustapha Mukatr of Department of environmental economics of Bayero University Kano (BUK) Kano Nigeria for his support and guidance. I also thanked the Kano State Refuse Management and Disposal Agency for their valuable support with all the relevant information during the writing of this paper.

\section{References}

[1]. Abbas I.I (2016) Dioxin emission and industrial solid waste in Kano metropolis, Nigeria E3 Journal of Environmental Research and Management Vol. 7(2). pp. 0029-0037, Available online http://www.e3journals.org.

[2]. Abu Salam (2007) Environmental and health impact of solid waste disposal at Mangwaneni dumpsite in Manzini: Swaziland. Available at: http://www.researchgate.net.

[3]. Angela et al., (2014) Household Solid Waste Management Practices and Health Implications among Urban Residents in Ruiru Municipality Kiambu County Kenya. IJRS. Vol.3 (7).

[4]. Aliyu N. (2010) An Analysis of Municipal solid Waste in Kano State Nigeria Jol. of Human Ecology 31(2):111-119.

[5]. Aliyu N. (2015) Institutional Constraints to Municipal solid Waste Management in Kano Metropolis Nigeria Inter Jol. of Env studies research Vol3. (3) 13-21.

[6]. Audu AJ (2013) Knowledge attitude And Practice on Waste Management in Jos South Metropolis Plateau State Med Jol of Social Sciences Vol.4 No 5.

[7]. Banjo AA, Adebambo AAR, Dairo OS (2009). Inhabitants' Perception on Domestic Waste Disposal in Ijebu Ode, Southwest Nigeria. Afr J. Basic Appl. Sci. 1(3-4): 62-66.

[8]. Beatrice A. (2013) Municipal solid waste Management Problems in Nigeria: Evolving Management Solution Int Jol. of Env. Chem. And Ecological and Geophysical Eng. Vol.7 No.6. 
[9]. Boardi (2005) Environmental and Public Health Impact of Household Solid Waste Handling Disposal Practice a case study of Accre Ghana Journal of Env Hlth Vol 68 No 4 p34- 46.

[10]. DEFRA (2004) Review of the Environmental and Health Effects of Waste Management: Municipal Solid Waste and Similar Waste, London: Queen's Printer and Controller of HMSO. Accessed athttp://www.defra.gov.uk/environment/waste/research/health/index.htm.

[11]. Energy News (2017) Negative impacts of incineration-based waste-to-energy technology. Energy new found at: http://www.alternative-energy-news.info/negative-impacts- waste-to-energy.

[12]. Longe (2009) People's Perception on Household Waste Management in Ojo LGA Lagos Nigeria Iran Jol. of Env. Health Sci and Eng Vol. 6 No3.

[13]. Modebe et al., (2009) Public Health Implication of Household solid Waste Management in Awka South East Nigeria Int Jol. of Public Health.

[14]. Muktar (2011) Constraints-to-Waste Management-in- Kano. Available on: http://mustaphamuktar.blogspot.com.ng.

[15]. Musa (2012) Human Health Implications of Waste Dump Cultivated Vegetables in Anyigba, Kogi State, Nigeria. Research Journal of Environmental and Earth Sciences 5(12): 710-713.

[16]. Nkwocha E, Pat-Mbano E, Dike M (2011). Evaluating the efficiency solid waste collection services Owerri municipality, Nigeria. International journal of science and nature; 2(1): 89-95.

[17]. Obiageli (2011) Practice, Pattern and Challenges of Solid Waste Management in Onitsha Metropolis, Nigeria. American Journal of Public Health Research, 2016, Vol. 4, No. 1, 16-22.

[18]. Onwugharsa etnal (2010) Issue of Roadside Disposal Habit of Municipal Solid Waste, Environmental impact and Implementation of sound Management Practices in Developing Countries Int Jol. of Env. Sci. and Dev Vol.1 No. 5 .

[19]. Pate FA. (2012) Groundwater Pollution Threats of Solid Waste Disposal in Urban Kano, Nigeria: Evaluation and Protection Strategies. PhD thesis submitted to The University of Manchester in the Faculty of Engineering and Physical Sciences School of Mechanical, Aerospace and Civil Engineering.

[20]. Peter (2011) Environmental Exposure and Public Health impacts of poor clinical waste treatment and disposal in Cameroon Publications of the University of Southern Denmark.

[21]. Pervez eta; (2013) Impact of Solid Waste on Health and the Environment. IJSD and Econs. No: V-2, 1.1,2.

[22]. Sridhar, M.K.C. and G.O. Adeoye, 1995. Waste management beyond the household. Proceedings of the National Conference on Seminar: Strategy on Household Waste Management, Nov. 13-14, Goethe Institute, Lagos, pp: 17-23.

[23]. Sridhar (1999) Waste Disposal and Environmental Hazard Control West Afrtica Health Examination Board (WHEB) Lagos Nigeria.

[24]. Tchobanoglous, G., \& Kreith, F. (2002). Handbook of solid waste management (2nd ed., p. 950). McGrawHill.

[25]. Tchobanoglous et'al (2006). Sustainable waste management at special events using reusable dishware: The example of whole earth festival at the University of California, Davis. Fresenius Environmental Bulletin, 15(8a), 822-828.

[26]. UNEP (2007) Environmental Pollution and Impacts on Public Health: Implications of the Dandora Municipal Dumping Site in Nairobi, Kenya Report Summary web: http://www.unep.org/urbanenvironment. 